\title{
Masked urinary bladder injury with a bullet expulsed spontaneously during voiding
}

\author{
Ateşli silah yaralanmasıyla oluşan gizli mesane yaralanması ve \\ kurşunun spontan miksiyonla üretradan atılması
}

\author{
Müjgan ÇALIŞKAN, ${ }^{1}$ İsmail EVREN, ${ }^{2}$ İsmail KABAK, ${ }^{1}$ İbrahim ATAK, ${ }^{1}$ Recai GÖKCAN ${ }^{3}$
}

We report a case with gunshot to the pelvis. The injury site was the soft tissue between the rectum and urinary bladder. Several days later, the bullet was expulsed spontaneously during voiding. In the literature, only a few case reports have described spontaneous expulsion of an intravesical bullet. A 19-year-old male was wounded on the left hip by gunshot. Radiographic examinations showed a bullet in the pelvis, which was localized in the soft tissue between the rectum and urinary bladder, with no accompanying visceral injury on abdominopelvic computerized tomography. Macroscopic hematuria was noticed after urethral catheterization. Rectosigmoidoscopy and retrograde cystoscopic examinations were both negative. The patient was monitored closely and treated conservatively with no surgical intervention. The urinary catheter was removed on the fifth postoperative day, and the bullet was expulsed spontaneously via the urethra during normal voiding three hours after catheter removal. Thereafter, a retrograde urethrography was performed, which showed no evidence of urinary tract or bladder injury.

Key Words: Bladder; gunshot wound; hip; penetrating pelvic trauma.

Gunshot wounds to the pelvis can result in injuries in various organ systems. High velocity penetrating pelvic injuries represent one of the most difficult and challenging situations for the emergency surgeons and require a multidisciplinary trauma team approach.

We report a case that suffered a gunshot to the pelvis. The injury site was the soft tissue between the rectum and urinary bladder. Several days later, the bullet was expulsed spontaneously via the urethra. In the lit-
$\mathrm{Bu}$ yazıda, ateşli silahla pelvis yaralanması olan hasta sunuldu. Yaralanma bölgesi mesane ve rektum arasındaki yumuşak doku idi. Birkaç gün sonra kurşun spontan miksiyon esnasında üretra yolu ile atıldı. Literatürde kurşunun kendiliğinden olarak üretra yolu ile atıldığı birkaç nadir olgu bildirilmiştir. On dokuz yaşında erkek hastanın sol kalçasında ateşli silah yaralanması mevcut idi. Hemodinamik olarak stabil olan hastaya yapılan direkt grafi ve bilgisayarlı tomografide pelvis içinde, mesane ve rektum arasındaki yumuşak dokuda, organ hasarı oluşturmayan kurşun tespit edildi. Üretral kateterizasyon sonucu makroskopik hematüri tespit edildi. Rektosigmoidoskopi ve retrograd sistoskopik değerlendirmeler negatif idi. Cerrahi girişim yapılmaksızın, hasta konservatif takip edildi. Beşinci gün, üriner kateteri çıkarıldıktan üç saat sonra kurşun üretradan kendiliğinden miksiyon esnasında atıldı. Bunun üzerine retrograd üretrosistografi yapıld, üriner trakt ve mesane hasarına rastlanmadi.

Anahtar Sözcükler: Mesane; kurşun yaralanması; kalça; penetran pelvis travmasi. erature, only a few case reports have described spontaneous expulsion of an intravesical bullet. ${ }^{[1-5]}$

\section{CASE REPORT}

A 19-year-old male wounded on the left hip by gunshot was referred to our medical center. As the patient was hemodynamically stable, it was possible to perform several radiographic and endoscopic studies, including computerized tomography, rectosigmoidoscopy, cystography, and retrograde urethrography, 
in addition to the clinical evaluation. The patient was normotensive. Physical examination showed two entrance wounds, one on the left side of the left hip and one on the left side of the right hip, and one exit wound on the right side of the left hip. Abdominal examination showed no suspected suprapubic or abdominal tenderness, and digital rectal examination showed no bleeding per rectum. Urinalysis showed hematuria and hematocrit was at $50.2 \%$. As there was no blood on the external urethral meatus, a urethral catheter was inserted. Urine was hematuric for about three hours. Plain pelvic films located the bullet as seen in Figure 1a. Abdominopelvic computerized tomography confirmed that the bullet was located in the soft tissue between the rectum and urinary bladder, with no accompanying visceral injury (Fig. 1b). The bladder was filled with $300 \mathrm{cc}$ contrast material and full and post-drainage cystograms were obtained, which were all negative, as was the retrograde urethrography (Fig. 1c). Thereafter, no cystoscopy was performed. Additionally, no injury was detected on rectosigmoidoscopy. The patient was monitored closely and treated conservatively with no surgical intervention. The urinary catheter was removed on the fifth postoperative day, and three hours after removal, the bullet was expulsed spontaneously during normal voiding (Fig. 1d). A retrograde urethrography was performed, which showed no evidence of urinary tract or bladder injury. The patient was discharged from the hospital on the same day, and at the follow-up visit one month after the trauma, he was completely normal without any complaint.

\section{DISCUSSION}

Due to the complex anatomy, pelvic gunshot wounds can result in various degrees of injuries in several organ systems. The most prevalent injuries have included soft tissue loss, pelvic bone fractures, vascular disruptions, and various genitourinary tract, rectum and bowel injuries. These injuries are often complex, morbidity and mortality rates are expected to be high, and a multidisciplinary trauma team approach is required in their management. In their series of 28 patients with severe penetrating pelvic injuries, Arthurs et al ${ }^{[6]}$ reported that the most lethal combination of injuries are hemorrhage and sepsis, vascular injury (particularly iliac vein) and rectal injury.
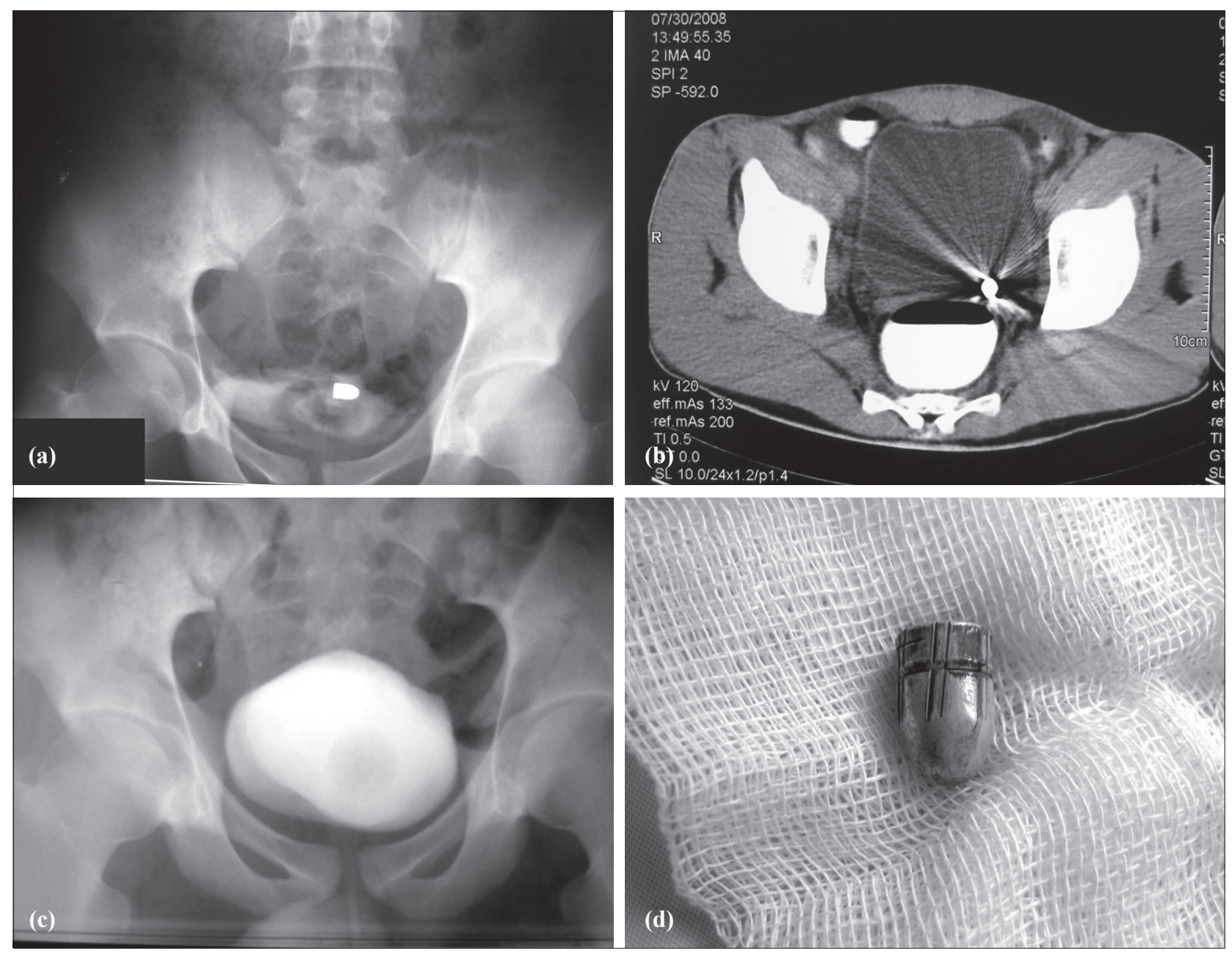

Fig. 1. (a) Plain pelvic X-ray. (b) Abdominal computerized tomography. (c) Retrograde cystography. (d) A view of the bullet. 
An empty bladder is much less vulnerable to injury. Using retrograde cystography, bladder injuries can be divided into extraperitoneal and intraperitoneal injuries. In extraperitoneal injuries, the treatment is catheter drainage and antibiotic treatment. The bladder usually heals in a few days. On the contrary, intraperitoneal injuries usually require surgical treatment. The healing of the bladder injury can be exhibited with cystography.

Our proposed explanation for this case is that the bullet was slowed because of the exit and a second entrance to the hip and was fixed to the wall of the urinary bladder. Edema formation had surrounded the bullet. During the healing of the bladder wall, the extravesical bullet surface was covered with epithelization, and due to subsequent bladder contractions, the bullet moved into the intravesical cavity. A few days later, a 7.65-caliber bullet was spontaneously expulsed via the urethra with normal urination.

Penetrating pelvic gunshot wounds require careful clinical follow-up with complete laboratory and radiological investigations, and a multidisciplinary trauma team approach is required in their management. Physicians should always be aware of the possibility of an immediate operation. Nevertheless, it remains exceptional to witness spontaneous passage of a bullet during normal voiding after a pelvic gunshot wound without any intrapelvic organ injuries.

\section{REFERENCES}

1. Kiliç D, Kilinç F, Ezer A, Guvel S. Spontaneous expulsion of a bullet via the urethra. Int J Urol 2004;11:576-7.

2. DiDomenico D, Guinan P, Sharifi R. Spontaneous expulsion of an intravesical bullet. J Am Osteopath Assoc 1997;97:4156.

3. Sankari BR, Parra RO. Spontaneous voiding of a bullet after a gunshot wound to the bladder: case report. J Trauma 1993;35:813-4.

4. Abdelsayed MA, Bissada NK, Finkbeiner AE, Redman JF. Spontaneous passage of bullet during voiding. South Med J 1978;71:83-4.

5. Cohen SP, Varma KR, Goldman SM. Spontaneous expulsion of intravesical bullet. Urology 1975;05:387-9.

6. Arthurs Z, Kjorstad R, Mullenix P, Rush RM Jr, Sebesta J, Beekley A. The use of damage-control principles for penetrating pelvic battlefield trauma. Am J Surg 2006;191:604-9. 